Revista Brasileira de Farmacognosia Brazilian Journal of Pharmacognosy 22(2): 418-427, Mar./Apr. 2012

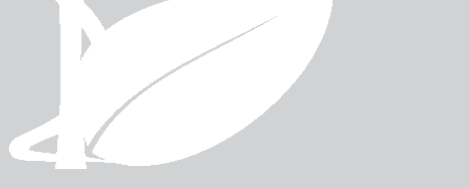

Article

Received 17 Dec 2010

Accepted 2 Aug 2011

Available online 21 Nov 2011

Keywords:

Ammannia baccifera

Blepharis maderaspatensis excision and incision model wound healing activity

ISSN 0102-695X http://dx.doi.org/10.1590/S0102$695 \times 2011005000207$

\section{Evaluation of wound healing activity of Ammannia baccifera and Blepharis maderaspatensis leaf extracts on rats}

\author{
Aiyalu Rajasekaran, ${ }^{, 1}$ Vellaichamy Sivakumar, ${ }^{2}$ Sabarimuthu \\ Darlinquine ${ }^{3}$
}

\author{
${ }^{1} \mathrm{KMCH}$ College of Pharmacy, Kovai Estate, Kalapatti Road, Coimbatore, Tamilnadu, \\ India, \\ ${ }^{2}$ Research scholar, Sastra University, Thanjavur, Tamilnadu, India, \\ ${ }^{3}$ Sastra University, Thanjavur, Tamilnadu, India.
}

\begin{abstract}
Wound healing activity of the leaf extracts of Ammannia baccifera L., Lythraceae, and Blepharis maderaspatensis (L.) B.Heyne ex Roth., Acanthaceae, was investigated by excision and incision wound healing models in rats. A phytochemical screening was done to determine the major constituents of the chloroform, ethyl acetate and ethanolic fractions of ethanolic leaf extracts. The excision and incision models were used to assess the effect of the plant extracts on wound healing in rats. Phytochemical screening reveals the presence of tannins, saponins, steroids, terpenoids, and flavonoids in the extract. The wound healing effect was comparatively evaluated with a standard drug Framycetin cream. Significant wound healing activity was observed for the creams prepared with $5 \%$ ethanol fraction of B. maderaspatensis and 5\% chloroform fraction of A. baccifera ethanolic leaf extracts. The results of histopathological evaluation supported the outcome of both incision and excision wound models. Ethanolic fraction of $B$. maderaspatensis and chloroform fraction of $A$. baccifera exhibited marked wound healing activity. B. maderaspatensis extract displayed a remarkable wound healing activity compared to $A$. baccifera.
\end{abstract}

\section{Introduction}

Many traditional practitioners across the world particularly in countries like India and China with age old traditional practices have valuable information of many lesser-known hitherto unknown wild plants used by the traditional healers for treating wounds and burns (Bhuvaneswar et al, 2010; Ignacimuthu et al., 2008). Healing of wounds is one of the important areas of clinical medicines explained in many Ayurvedic texts under the heading "Vranaropaka" (Kumar et al., 2007). Medicinal plants have been used since time immemorial for treatment of various ailments of skin and dermatological disorders especially cuts, wounds and burns. Wound healing disorders present a serious clinical problem and are likely to increase since they are associated with diseases such as diabetes, hypertension and obesity. In India, there has been potential interest in search of medicinal plants for development of drugs with wound healing properties as taught in a popular form of Indian medicine known as Ayurveda (Jain et al., 2006).
Blepharis maderaspatensis (L.) B.Heyne ex Roth., Acanthaceae, is known as "Nethirapoondu", in Tamil, is a prostrate, creeping, wiry plant, rooting at the nodes. It is seen commonly on slopes among rocks, poor gravelly soil on the hills up to $1400 \mathrm{~m}$. It is used to treat the disorders such as boils, bone fracture, diarrhea and lactation (Ayyanar et al., 2008). Paste of leaves is mixed with limejuice and applied on cuts (Ignacimuthu et al., 2006). The leaves of BM and the yellow yolks of two eggs ground into a fine paste are applied on fractured bones in traditional practice (Kottaimuthu, 2008).

Ammannia baccifera L., Lythraceae, "Neermalneruppu" in Tamil is an erect glabrous reddish herb grows upto $60 \mathrm{~cm}$ in height. The extract of whole plant is used in the healing of wounds (Vanila et al., 2008). Paste of the leaves was used in traditional practice to relieve swelling (Ganesan et al., 2007).

The leaves of both the plants were used in traditional practice for wound healing, but there are no scientific reports on any wound healing activity of these plants and hence the present study was undertaken. 


\section{Material and Methods}

\section{Collection and authentication of plant material}

The plants were collected during the month of November from the Western Ghats of Srivilliputtur was authenticated by Mr. V. Chelladurai, Research officer of botany, CCRAS, Government of India. The voucher specimen number. CED/Herbarium/A 0012 for Ammannia baccifera L., Lythraceae, and the voucher specimen number. CED/Herbarium/B 0008 for Blepharis maderaspatensis (L.) B.Heyne ex Roth., Acanthaceae, has been deposited in the herbarium maintained by Centre for Endogenous Development, Department of Pharmacognosy, Arulmigu Kalasalingam College of Pharmacy, India. The collected plant materials were dried at room temperature under shade for fifteen days and then it was blended into coarse powder by electrical grinder. The powdered leaves were stored in a dessicator for extraction.

\section{Plant extraction and fractionation}

About $900 \mathrm{~g}$ of air dried coarse powder of B. maderaspatensis were soaked in ethanol procured from atmosphere for seven days with occasional shaking. The ethanol soluble residue was filtered off and concentrated under vacuum at room temperature using rotary evaporator which yielded a dark greenish semisolid material (67.12 g). The concentrated extract was mixed with small quantity of water and sequentially fractionated with chloroform, ethyl acetate and aqueous ethanol yielded 33.68, 14.22 and 52.1\% w/w residues respectively. Similar procedure was adopted for $A$. baccifera which yielded dark brownish residue $(98.12 \mathrm{~g})$. The concentrated extract was mixed with small quantity of water and sequentially fractionated with chloroform, ethyl acetate and aqueous ethanol yielded $42.12 \%, 10.24 \%$ and $47.64 \% \mathrm{w} / \mathrm{w}$ residues respectively.

\section{Phytochemical screening}

The phytochemical screening was done according to the references to the following chemical groups: saponins (Kapoor et al., 1969), tannins (Kapoor et al., 1969), terpenoids (Said, 1956), alkaloids and flavonoids (Harborne, 1998).

\section{Animals}

Healthy Wistar albino rats of either sex and of approximately the same age, weighing about 150-250 g were used for the study and they were procured from Perundurai medical college, Perundurai, Erode district, Tamilnadu, India. They were fed with standard diet and water ad libitum. They were housed in polypropylene cages maintained under standard lab conditions $(12 / 12$ $\mathrm{h}$ light/dark cycle; $\left.25-30{ }^{\circ} \mathrm{C}, 35-60 \% \mathrm{RH}\right)$. Experiments were conducted in accordance with the internationally accepted principles of laboratory animal use and care. The study protocol was approved by the Institutional Animal Ethics Committee (509/02/C/CPCSEA/2002) for the purpose of control and supervision of animals (CPCSEA, New Delhi.) conducted on $22^{\text {nd }}$ December 2008.

\section{Preparation of creams}

A 2.5 and $5 \%(\mathrm{w} / \mathrm{w})$ of chloroform fraction of ethanolic leaf extracts of B. maderaspatensis was prepared by mixing 2.5 and $5 \mathrm{~g}$ of chloroform fraction respectively with the required molten mixture of white soft paraffin, cetostearyl alcohol, polysorbate 60 and butylated hydroxyl anisole as stated in Table 1. (C-I\&C-II). Similarly chloroform fraction of ethanolic leaf extracts of $A$. baccifera was prepared (C-VII\&CVIII) (Jagtap et al., 2009).

A 2.5 and $5 \%(\mathrm{w} / \mathrm{w})$ of ethyl acetate fraction of ethanolic leaf extracts of $B$. maderaspatensis was prepared by mixing 2.5 and $5 \mathrm{~g}$ of ethyl acetate fraction respectively with molten mixture of white soft paraffin, cetostearyl alcohol and polysorbate 60 and butylated hydroxyl anisole (C-III\&C-IV). Similarly ethyl acetate fraction of ethanolic leaf extracts of $A$. baccifera was prepared (C-IX\&C-X) (Jagtap et al., 2009).

A 2.5 and $5 \%(\mathrm{w} / \mathrm{w})$ of ethanolic fraction of ethanolic leaf extracts of B. maderaspatensis was prepared by dissolving 2.5 and $5 \mathrm{~g}$ of ethanolic fraction in purified water, glycerine was added and heated to $70{ }^{\circ} \mathrm{C}$ respectively. Then the molten mixture of white soft paraffin, cetostearyl alcohol, polysorbate 60 and butylated hydroxyl anisole was added to it with continuous stirring until it becomes semisolid (C-V\&C-VI). Similarly ethanolic fraction of ethanolic leaf extracts of $A$. baccifera was prepared (C-XI\&CXII) (Jagtap et al., 2009). The details of experimental group treated with the creams are recorded in Table 2.

\section{Acute dermal toxicity - fixed dose}

The acute dermal toxicity study was carried out in adult albino rats of both sexes by "fix dose" method of OECD (Organization for Economic Co-operation and Development) Guideline No.434 (OECD, 1987). The temperature of the experimental animal room was $22{ }^{\circ} \mathrm{C}$ $( \pm 2)$ and the relative humidity was $30-70 \%$, where the lightings were artificial and the sequence was $12 \mathrm{~h}$ light 
$12 \mathrm{~h}$ dark. The prepared creams with fractions/extracts of both the plants were applied topically at a dose level of $2000 \mathrm{mg} / \mathrm{kg}$ on the shaved part of five animals in each group for fourteen days. The creams were applied with porous gauze dressing to make contact with the skin. The animals were observed for any changes in skin rashes or dermatitis or death.

Table 1. Ingredients for the preparation of creams.

\begin{tabular}{lc}
\hline \multicolumn{1}{c}{ Ingredients } & Quantity (g) \\
\hline $\mathrm{CHCl}_{3} /$ EtOAc/EtOH fraction of ethanolic leaf & $2.5 / 5$ \\
extract of $B$. maderaspatensis/A. baccifera & \\
Polysorbate 60 & 5 \\
White Soft Paraffin & 25 \\
Cetosteryl alcohol & 4 \\
Glycerin & 12 \\
Butylated hydroxyl anisole & 0.02 \\
Purified water & q.s to 100 \\
\hline
\end{tabular}

\section{Wound healing models}

Wound healing activity was studied using two models viz. excision wound model and incision wound model

\section{Excision wound model}

Animals were divided into fourteen groups $(1-14 ; \mathrm{n}=6)$ and anaesthetized with chloroform and excision wounds $(2.5 \mathrm{~cm}$ diameter $)$ created on the depilated dorsal thoracic region (Morton \& Malone 1972). An impression was made on the dorsal thoracic region $1 \mathrm{~cm}$ away from vertebral column and 5 $\mathrm{cm}$ away from ear using round seal of 2,5 $\mathrm{cm}$ diameter on the anaesthetized rat. The skin of impressed area was excised to the full thickness to obtain a wound area of about $500 \mathrm{~mm}^{2}$. Haemostasis was achieved by blotting the wound with cotton swab soaked in normal saline. The animals of group 3 to group 14 were applied with the creams C I-C XII once daily on the wounds respectively, while the group 1 was applied with the cream base alone and the group 2 was applied with the standard Framycetin cream. Contractions, which contribute for wound closure in first 2 weeks, were studied by tracing the raw wound. Wound area was measured by retracing the wound on a millimeter scale graph paper (Suresh Reddy et al, 2002). The wound diameter was measured on alternate days and the epithelialization period recorded at the end of the study. Wound contraction (\%) was calculated using the following formula: (Okoli et al, 2009)

Wound contraction $(\%)=\left[\left(\mathrm{WD}_{0}-\mathrm{WD}_{\mathrm{t}}\right) / \mathrm{WD} 0\right] 100$ where: $\mathrm{WD}_{0}=$ the wound diameter on day zero; $\mathrm{WDt}=$ the wound diameter on day $\mathrm{t}$.

Table 2. Description of experimental group.

\begin{tabular}{|c|c|c|c|}
\hline Formulation & $\begin{array}{c}\text { Formulation } \\
\text { code }\end{array}$ & $\begin{array}{l}\text { Weight of the } \\
\text { extract used in } g\end{array}$ & Description \\
\hline Cream I & C-I & 2.5 & $\begin{array}{l}\mathrm{CHCl}_{3} \text { fraction } \\
\text { of ethanolic leaf } \\
\text { extract of } B \text {. } \\
\text { maderaspatensis }\end{array}$ \\
\hline Cream II & C-II & 5 & $\begin{array}{l}\mathrm{CHCl}_{3} \text { fraction } \\
\text { of ethanolic leaf } \\
\text { extract of } B \text {. } \\
\text { maderaspatensis }\end{array}$ \\
\hline Cream III & C-III & 2.5 & $\begin{array}{l}\text { EtOAc fraction } \\
\text { of ethanolic leaf } \\
\text { extracts of } B \text {. } \\
\text { maderaspatensis }\end{array}$ \\
\hline Cream IV & C-IV & 5 & $\begin{array}{l}\text { EtOAc fraction } \\
\text { of ethanolic leaf } \\
\text { extract of } B \text {. } \\
\text { maderaspatensis }\end{array}$ \\
\hline Cream V & $\mathrm{C}-\mathrm{V}$ & 2.5 & $\begin{array}{l}\text { EtOH fraction } \\
\text { of ethanolic } \\
\text { leaf extract } B \text {. } \\
\text { maderaspatensis }\end{array}$ \\
\hline Cream VI & $\mathrm{C}-\mathrm{VI}$ & 5 & $\begin{array}{c}\text { EtOH fraction } \\
\text { of ethanolic } \\
\text { leaf extract } B \text {. } \\
\text { maderaspatensis }\end{array}$ \\
\hline Cream VII & C-VII & 2.5 & $\begin{array}{l}\mathrm{CHCl}_{3} \text { fraction } \\
\text { of ethanolic } \\
\text { leaf extract of } \\
\text { A.baccifera }\end{array}$ \\
\hline Cream VIII & C-VIII & 5 & $\begin{array}{c}\mathrm{CHCl}_{3} \text { fraction } \\
\text { of ethanolic leaf } \\
\text { extract of } A \text {. } \\
\text { baccifera }\end{array}$ \\
\hline Cream IX & C-IX & 2.5 & $\begin{array}{c}\text { EtOAc fraction } \\
\text { of ethanolic leaf } \\
\text { extract of } A \text {. } \\
\text { baccifera }\end{array}$ \\
\hline Cream X & $\mathrm{C}-\mathrm{X}$ & 5 & $\begin{array}{c}\text { EtOAc fraction } \\
\text { of ethanolic leaf } \\
\text { extract of } A . \\
\text { baccifera }\end{array}$ \\
\hline Cream XI & $\mathrm{C}-\mathrm{XI}$ & 2.5 & $\begin{array}{l}\text { EtOH fraction } \\
\text { of ethanolic leaf } \\
\text { extract of } A \text {. } \\
\text { baccifera }\end{array}$ \\
\hline Cream XII & C-XII & 5 & $\begin{array}{c}\text { EtOH fraction } \\
\text { of ethanolic leaf } \\
\text { extract of } A \text {. } \\
\text { baccifera }\end{array}$ \\
\hline
\end{tabular}

\section{Resutured incision wound}

All the animals were anaesthetized and the back hairs of the rats were shaved by using a shaving machine. Two paravertebral straight incisions of $6 \mathrm{~cm}$ length each were made through the entire thickness of 
the skin, on either side of the vertebral column with the help of a sharp scalpel (Ehrlich \& Hunt, 1968). After complete haemostasis the wound were closed by means of interrupted sutures placed at equidistance points about $1 \mathrm{~cm}$ apart. The test formulations, cream base and standard Framycetin cream, were applied on wound once daily for seven days. The sutures were removed on day 8 and wound tensile strength was measured on day 10 by using constant water flow technique by Lee et al (Lee, 1968).

\section{Constant water flow technique}

On the $10^{\text {th }}$ day the animals was secured to the operation table, under light ether anesthesia. A line was drawn on normal skin on either side of wound, 3 $\mathrm{mm}$ away from the wound line. Two Allis forceps were firmly applied on the lines facing each other. On one side the forceps was hooked firmly to metal rod fixed to the operation table. The other forceps was connected to a leak proof graduated polythene container through a string running over a pulley. The polythene container was connected to water reservoir placed at suitable height through a rubber tube kept occluded with a pinchcock. To measure wound tensile strength, the tube was released to allow a constant and continuous flow of water from the reservoir in to the polythene container. As the weight gradually increases, it acts as a pulling force to disrupt the wound. As soon as the gapping of the wound was observed, the rubber tube was clamped and the polythene container was weighed. Averages of six readings were taken from each animal of a group.

\section{Histopathological study}

Skin tissues were collected and transferred to $10 \%$ neutral buffered formalin for $24 \mathrm{~h}$ at $4{ }^{\circ} \mathrm{C}$. The formalin-fixed tissues were dehydrated through grades of alcohol and cleared in xylene and then embedded in paraffin wax $\left(58-60{ }^{\circ} \mathrm{C}\right)$. Five to $7 \mu \mathrm{m}$ sections were deparaffinized and stained with hematoxylin, and then counterstained with eosin (Mcmanus \& Mowry, 1984).

\section{Statistical analysis}

Results are expressed as mean \pm SD. The differences between experimental groups were compared by student t' test (control vs. treatment) and was considered statistically highly significant when $p<0.01$ and significant when $p<0.05$.

\section{Results and Discussion}

Phytochemical analysis
The phytochemical screening of the ethanolic extracts and its chloroform, ethyl acetate and ethanolic fractions of Ammannia baccifera L., Lythraceae, and Blepharis maderaspatensis (L.) B.Heyne ex Roth., Acanthaceae, revealed the presence of tannins, saponins, steroids, terpenoids, and flavonoids and absence of alkaloids. It was reported that the flavonoids and saponins possess significant wound healing activity (Pritam \& Sanjai, 2010).

\section{Acute dermal toxicity}

A study of acute toxicity by the dermal (percutaneous) route provides an estimate of the relative toxicity of a substance by the dermal route of exposure. Rats of either sex applied with the extracts upto a dose of $2000 \mathrm{mg} / \mathrm{kg}$ for fourteen days did not produced any signs of toxicity and mortality. The animals were observed for tremors, convulsions, salivation, diarrhoea, lethargy, sleep behavioural and clinical abnormalities, gross lesions, body weight changes and coma from day 1 to 14 days. The animals were found to be physically active and they were consuming food and water in a regular way.

\section{Excision wound model}

The results of the wound healing activity of the extracts by excision wound model are shown in Table 3 and Figure.1. In excision wound, the creams prepared with ethanolic fraction of B. maderaspatensis and chloroform fraction of ethanolic extract of $A$. baccifera showed faster wound contraction compared with control groups (Figure 3). Significant wound healing property was observed for the groups treated with standard framycetin cream, C-VI and C-VIII. The percentage of closure of wound was also found to be significant where the animals treated with cream VI and cream VIII showed $96.15 \%$ and $81 \%$ of contraction on $10^{\text {th }}$ day and complete contraction of wound on day $14^{\text {th }}$ respectively. The time required for complete epithelialisation of the excision wound is an important parameter to assess the wound healing process. It was found that the mean time taken for complete epithelialisation of the excision wound in cream VI and cream VIII treated was found to be equal to that of standard Framycetin cream treated. The group treated with cream VI had a faster wound contraction than that of the standard. All the other treated groups showed less wound healing activity.

\section{Resutured incision wound}

The promotion of wound healing activity is also well gazed by its tensile strength of the incision 
Table 3. Effect of creams prepared with $2.5 \% \mathrm{w} / \mathrm{w} \& 5 \% \mathrm{w} / \mathrm{w}$ chloroform/ethyl acetate/ethanol fraction of ethanolic extract of $B$. maderaspatensis and $A$. baccifera on excision wound model.

\begin{tabular}{|c|c|c|c|c|c|c|c|c|}
\hline \multirow{2}{*}{ Treatment } & \multicolumn{8}{|c|}{ Wound area $\left(\mathrm{mm}^{2}\right) \pm$ SEM } \\
\hline & Day 0 & Day 2 & Day 4 & Day 6 & Day 8 & Day 10 & Day 12 & Day 14 \\
\hline Group1 & $\begin{array}{c}24.78 \pm 1.17 \\
(0.00)\end{array}$ & $\begin{array}{c}22.94 \pm 0.86 \\
\quad(7.43)\end{array}$ & $\begin{array}{c}21.02 \pm 0.56 \\
(15.17)\end{array}$ & $\begin{array}{c}17.56 \pm 0.13 \\
(29.14)\end{array}$ & $\begin{array}{c}12.86 \pm 0.13 \\
(48.1)\end{array}$ & $\begin{array}{c}8.47 \pm 0.12 \\
(65.82)\end{array}$ & $\begin{array}{c}4.17 \pm 0.09 \\
(83.17)\end{array}$ & $\begin{array}{c}2.83 \pm 0.11 \\
(88.58)\end{array}$ \\
\hline Group 2 & $\begin{array}{c}24.56 \pm 1.15 \\
(0.00)\end{array}$ & $\begin{array}{c}21.9 \pm 0.99 \\
(10.83)\end{array}$ & $\begin{array}{c}18.8 \pm 0.2 \\
(23.45)\end{array}$ & $\begin{array}{c}11.4 \pm 0.28 \\
(53.58)\end{array}$ & $\begin{array}{c}5.56 \pm 0.08 \\
(77.36)\end{array}$ & $\begin{array}{c}1.55 \pm 0.24 \\
(93.69)\end{array}$ & $\begin{array}{c}0.35 \pm 0.00 \\
(98.57)\end{array}$ & $\begin{array}{c}0.00 \pm 0.00 \\
(100)\end{array}$ \\
\hline Group 3 & $\begin{array}{c}24.91 \pm 1.17 \\
(0.00)\end{array}$ & $\begin{array}{c}22.82 \pm 0.94 \\
(8.39)\end{array}$ & $\begin{array}{c}21.09 \pm 0.28 \\
(15.34)\end{array}$ & $\begin{array}{c}16.76 \pm 0.42 \\
(32.72)\end{array}$ & $\begin{array}{c}12.16 \pm 0.12 \\
(51.18)\end{array}$ & $\begin{array}{c}7.5 \pm 0.28 \\
(69.89)\end{array}$ & $\begin{array}{c}3.93 \pm 0.13 \\
(84.22)\end{array}$ & $\begin{array}{c}1.2 \pm 0.34 \\
(95.18)\end{array}$ \\
\hline Group 4 & $\begin{array}{c}24.86 \pm 1.19 \\
(0.00)\end{array}$ & $\begin{array}{c}22.83 \pm 0.81 \\
(8.17)\end{array}$ & $\begin{array}{c}20.42 \pm 0.09 \\
(16.69)\end{array}$ & $\begin{array}{c}15.34 \pm 0.18 \\
(37.41)\end{array}$ & $\begin{array}{c}10.8 \pm 0.21 \\
(55.94)\end{array}$ & $\begin{array}{c}6.6 \pm 0.19 \\
(73.07)\end{array}$ & $\begin{array}{c}2.4 \pm 0.14 \\
(90.21)\end{array}$ & $\begin{array}{c}0.42 \pm 0.12 \\
(98.29)\end{array}$ \\
\hline Group 5 & $\begin{array}{c}24.51 \pm 1.17 \\
(0.00)\end{array}$ & $\begin{array}{c}23.02 \pm 0.94 \\
(6.08)\end{array}$ & $\begin{array}{c}21.69 \pm 0.28 \\
(11.51)\end{array}$ & $\begin{array}{c}17.76 \pm 0.42 \\
(27.54)\end{array}$ & $\begin{array}{c}12.45 \pm 0.12 \\
\quad(49.2)\end{array}$ & $\begin{array}{c}8.12 \pm 0.28 \\
(66.87)\end{array}$ & $\begin{array}{c}4.03 \pm 0.13 \\
(83.56)\end{array}$ & $\begin{array}{c}2.14 \pm 0.48 \\
(91.27)\end{array}$ \\
\hline Group 6 & $\begin{array}{c}24.92 \pm 2.09 \\
(0.00)\end{array}$ & $\begin{array}{c}23.31 \pm 0.92 \\
\quad(6.46)\end{array}$ & $\begin{array}{c}21.02 \pm 0.18 \\
(15.65)\end{array}$ & $\begin{array}{c}16.71 \pm 0.24 \\
(32.95)\end{array}$ & $\begin{array}{c}11.91 \pm 0.08 \\
(52.21)\end{array}$ & $\begin{array}{c}7.67 \pm 0.09 \\
(69.22)\end{array}$ & $\begin{array}{c}3.62 \pm 0.08 \\
(85.47)\end{array}$ & $\begin{array}{c}1.12 \pm 0.34 \\
(95.51)\end{array}$ \\
\hline Group 7 & $\begin{array}{c}24.16 \pm 1.23 \\
(0.00)\end{array}$ & $\begin{array}{c}22.93 \pm 0.81 \\
\quad(5.09)\end{array}$ & $\begin{array}{c}20.12 \pm 0.09 \\
(16.72)\end{array}$ & $\begin{array}{c}14.34 \pm 0.18 \\
(40.65)\end{array}$ & $\begin{array}{c}9.88 \pm 0.21 \\
(59.11)\end{array}$ & $\begin{array}{c}5.66 \pm 0.19 \\
(76.57)\end{array}$ & $\begin{array}{c}1.4 \pm 0.14 \\
(94.21)\end{array}$ & $\begin{array}{c}0.12 \pm 0.12 \\
(99.5)\end{array}$ \\
\hline Group 8 & $\begin{array}{c}24.66 \pm 1.84 \\
(0.00)\end{array}$ & $\begin{array}{c}22.14 \pm 0.99 \\
(10.22)\end{array}$ & $\begin{array}{c}19.18 \pm 0.2 \\
(22.22)\end{array}$ & $\begin{array}{c}12.14 \pm 0.28 \\
(50.77)\end{array}$ & $\begin{array}{c}5.36 \pm 0.08 \\
(78.26)\end{array}$ & $\begin{array}{c}0.95 \pm 0.24 \\
(96.15)\end{array}$ & $\begin{array}{c}0.15 \pm 0.00 \\
(99.39)\end{array}$ & $\begin{array}{c}0.00 \pm 0.00 \\
(100)\end{array}$ \\
\hline Group 9 & $\begin{array}{c}24.73 \pm 1.92 \\
(0.00)\end{array}$ & $\begin{array}{c}23.12 \pm 0.98 \\
(6.51)\end{array}$ & $\begin{array}{c}20.56 \pm 1.23 \\
(16.86)\end{array}$ & $\begin{array}{c}16.12 \pm 0.87 \\
(34.82)\end{array}$ & $\begin{array}{c}11.54 \pm 0.59 \\
(53.34)\end{array}$ & $\begin{array}{c}7.45 \pm 1.01 \\
(69.87)\end{array}$ & $\begin{array}{c}3.67 \pm 0.43 \\
(85.16)\end{array}$ & $\begin{array}{c}1.04 \pm 0.32 \\
(95.79)\end{array}$ \\
\hline Group 10 & $\begin{array}{c}24.52 \pm 1.86 \\
(0.00)\end{array}$ & $\begin{array}{c}22.93 \pm 0.81 \\
(6.48)\end{array}$ & $\begin{array}{c}19.12 \pm 0.09 \\
(22.02)\end{array}$ & $\begin{array}{c}14.34 \pm 0.18 \\
(41.52)\end{array}$ & $\begin{array}{c}6.88 \pm 0.21 \\
(71.94)\end{array}$ & $\begin{array}{c}4.66 \pm 0.19 \\
(81)\end{array}$ & $\begin{array}{c}0.63 \pm 0.14 \\
(97.43)\end{array}$ & $\begin{array}{c}0.00 \pm 0.00 \\
(100)\end{array}$ \\
\hline Group 11 & $\begin{array}{c}24.32 \pm 1.74 \\
(0.00)\end{array}$ & $\begin{array}{c}23.22 \pm 0.92 \\
\quad(4.52)\end{array}$ & $\begin{array}{c}22.23 \pm 0.18 \\
\quad(8.59)\end{array}$ & $\begin{array}{c}17.65 \pm 0.24 \\
(27.43)\end{array}$ & $\begin{array}{c}12.89 \pm 0.08 \\
(47)\end{array}$ & $\begin{array}{c}7.46 \pm 0.09 \\
(69.33)\end{array}$ & $\begin{array}{c}4.24 \pm 0.08 \\
(82.57)\end{array}$ & $\begin{array}{c}2.52 \pm 0.34 \\
(89.64)\end{array}$ \\
\hline Group 12 & $\begin{array}{c}24.92 \pm 2.09 \\
(0.00)\end{array}$ & $\begin{array}{c}23.12 \pm 0.92 \\
\quad(7.22)\end{array}$ & $\begin{array}{c}21.92 \pm 0.18 \\
(12.04)\end{array}$ & $\begin{array}{c}15.71 \pm 0.24 \\
(36.96)\end{array}$ & $\begin{array}{c}10.91 \pm 0.08 \\
(56.22)\end{array}$ & $\begin{array}{c}6.67 \pm 0.09 \\
(73.23)\end{array}$ & $\begin{array}{c}3.62 \pm 0.08 \\
(85.47)\end{array}$ & $\begin{array}{c}2.12 \pm 0.34 \\
(91.49)\end{array}$ \\
\hline Group 13 & $\begin{array}{c}24.42 \pm 1.80 \\
\quad(0.00)\end{array}$ & $\begin{array}{c}22.82 \pm 0.94 \\
(6.55)\end{array}$ & $\begin{array}{c}21.69 \pm 0.28 \\
(11.18)\end{array}$ & $\begin{array}{c}16.32 \pm 0.42 \\
(33.17)\end{array}$ & $\begin{array}{c}12.72 \pm 0.12 \\
(47.91)\end{array}$ & $\begin{array}{c}6.35 \pm 0.28 \\
(74)\end{array}$ & $\begin{array}{c}4.23 \pm 0.13 \\
(82.68)\end{array}$ & $\begin{array}{c}1.28 \pm 0.34 \\
(94.76)\end{array}$ \\
\hline Group 14 & $\begin{array}{c}24.76 \pm 1.90 \\
(0.00)\end{array}$ & $\begin{array}{c}22.83 \pm 0.81 \\
\quad(7.79)\end{array}$ & $\begin{array}{c}20.26 \pm 0.09 \\
\quad(18.17)\end{array}$ & $\begin{array}{c}15.34 \pm 0.18 \\
(38.05)\end{array}$ & $\begin{array}{c}10.38 \pm 0.21 \\
(58.08)\end{array}$ & $\begin{array}{c}5.86 \pm 0.19 \\
(76.33)\end{array}$ & $\begin{array}{c}2.14 \pm 0.14 \\
(91.36)\end{array}$ & $\begin{array}{c}0.52 \pm 0.12 \\
(97.9)\end{array}$ \\
\hline
\end{tabular}

wound. Generally wound healing agents have the properties to enhance the deposition of collagen content, which provides strength to the tissues and forms crosslinkages between collagen fibers (Madden \& Peacock, 1968). The tensile strength of the incision wound was significantly increased in the animals treated with cream VI and cream VIII and was comparably the same of standard framycetin cream. The increase in tensile strength of treated wounds may be due to the increase in collagen concentration, stabilization of the fibers and enhanced action of myofibroblasts which are responsible for the elasticity of the tissue (Udupa et al., 1995). Moderate gains in tensile strength were observed in C-I and C-II treated animals. Increasing the concentration of the extracts in the creams produced increased response which is evident from the data depicted in Table 4 and Figure.2.

\section{Histopathological study}

The histopathological study depicted in Figures 4, 5, 6 and 7 revealed that the group 1 treated with cream base alone showed a large area of ulceration covered by fibrin, capillaries, fibroblasts and inflammatory cells. The dermis under and beyond showed fibro vascular proliferation with few lymphocytes, few thick collagen fibers, neutrophils and mast cells. Thick walled blood vessels were present at the base. The lesser epithelialization and lesser collagen formation indicated incomplete healing of the wound in control animals. Group 2 treated with standard Framycetin cream showed focal ulceration and replacement of dermis and skeletal muscle by cellular fibrous tissue, capillaries and a few broad collagen fibers. The wound had healed well and is covered by stratified squamous epithelium. The group 8 treated with the cream VI containing $5 \%$ of ethanol fraction of $B$. maderaspatensis showed dermal fibrosis with collagen stands and bands. The wound has healed well and is covered with squamous epithelium and there is fibrous replacement of the dermis. The group 10 treated with $\mathrm{C}$-VIII showed skin subcutis and skeletal muscle. There is a focus of cellular fibrous tissue with capillaries and wavy 
collagen fibers replacing the dermis and skeletal muscle. The epidermis over this is thick, but lacks rete ridges and shows focal ulceration. There is fibrous replacement in the dermis.

Table 4. Effect of creams prepared with $2.5 \% \mathrm{w} / \mathrm{w} \&$ $5 \% \mathrm{w} / \mathrm{w}$ chloroform/ethyl acetate/ethanol fraction of $B$. maderaspatensis and $A$. baccifera on incision wound model.

\begin{tabular}{lcc}
\hline Treatment Groups & $\begin{array}{c}\text { Complete wound } \\
\text { healing in days }\end{array}$ & Tensile strength in g \\
\hline Group 1 & 19.5 & $199.52 \pm 13.04$ \\
Group 2 & $14.66^{* *}$ & $381.32 \pm 12.95^{* *}$ \\
Group 3 & $15.83^{*}$ & $340.39 \pm 12.78^{*}$ \\
Group 4 & $14.83^{*}$ & $372.98 \pm 13.95^{*}$ \\
Group 5 & 17.82 & $256.45 \pm 11.42$ \\
Group 6 & 16 & $310.23 \pm 12.34$ \\
Group 7 & $14.32^{* *}$ & $380.43 \pm 18.74^{* *}$ \\
Group 8 & $13.5^{* *}$ & $392.46 \pm 14.59$ \\
Group 9 & $16^{*}$ & $301.32 \pm 17.42$ \\
Group 10 & $14.66^{* *}$ & $378.65 \pm 13.45^{* *}$ \\
Group 11 & 18.32 & $220.94 \pm 14.20$ \\
Group 12 & 17.66 & $260.92 \pm 9.45$ \\
Group 13 & $16.32^{*}$ & $298.52 \pm 10.23$ \\
Group 14 & $14.83^{*}$ & $370.43 \pm 19.65^{* *}$ \\
\hline
\end{tabular}

Significant data analyzed by student ' $\mathrm{t}$ ' test compared with control vs treatment are given as $* p<0.05 * * p<0.01$.

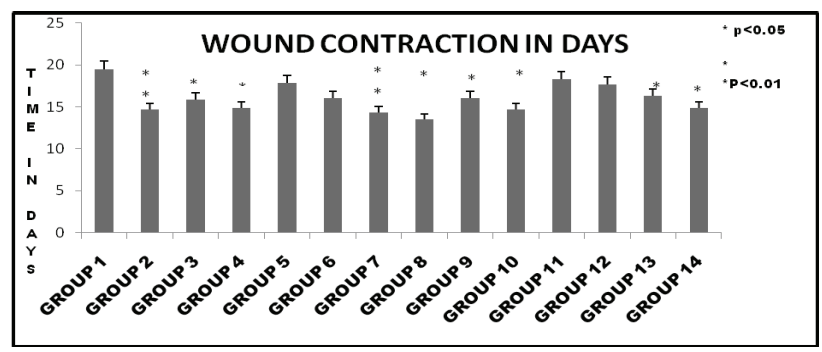

Figure 1. Effect of different creams on wound contraction on excision wounded rats. Results are presented as mean $\pm \mathrm{SD}$. statistically significant data analyzed by student ' $\mathrm{t}$ ' test compared with control vs treatment are given as $* p<0.05$ $* * p<0.01$.

The present investigation describes some unique features of the leaf extract from the medicinal plants of $A$. baccifera and $B$. maderaspatensis with respect to its wound healing activity. These plants were preferred for the evaluation of wound healing activity because of their wide spread availability, non-toxicity, absence of unwanted side effects and effectiveness as crude preparations. The fractions of the ethanolic extract of both the plants revealed the presence of terpenoids, phytosterols, flavonoids and tannins. Terpenoids are known to promote wound healing process, mainly due to their astringent and antimicrobial properties which seems to be responsible for wound contraction and increased rate of epithelialization (Scortichini, 1991). Terpenoids may have great antifungal or antimicrobial potential due to possible effect on the non-mevalonate pathway. This pathway is essential in fungi, protozoans, gram-negative bacteria and other micro-organisms for the synthesis of cell membrane components, prenylation proteins and as a secondary source of carbon (Nayak et al., 2010). Studies with other plant materials also demonstrated the presence of similar phytochemical constituents, which were responsible for promoting wound healing activity in rats (Nayak, 2006). The topical application is an efficient therapy method of destroying microbial populations because the availability of the drug at the infected wound site leads to enhanced wound healing activity. The virulence capacity of microorganisms, amount of inoculums, and host immune response are important factors that can cause massive damage during infection. Leaf extracts of $A$. baccifera and B. maderaspatensis acts as a stimulant for wound healing because it has polyphenols and flavonoids as active constituents. After injury, revascularization of the wound bed and redevelopment of the extracellular matrix are achieved through cell proliferation and the production of granulation tissue. Wound contraction, a part of the proliferative phase of wound healing, occurs through the centripetal movement of the tissues surrounding the wound, which is mediated by myofibroblasts (Adam, 1999). A significant increase in collagen content due to enhanced migration of fibroblasts and epithelial cells to the wound site was observed during the wound healing process in the treated group.

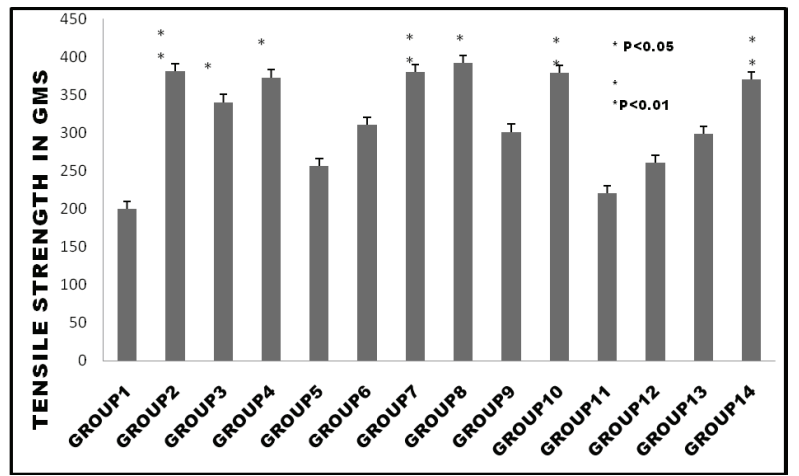

Figure 2. Effect of different creams on tensile strength in $g$ on incision wounded rats. Results are presented as mean $\pm \mathrm{SD}$. Statistically significant data are given as ${ }^{*} p<0.05 * *_{p}<0.01$.

The increased cellular infiltration observed from hematoxylin and eosin staining in treated groups may be due to the presence of pathogens. Early dermal and epidermal regeneration in the treated group confirmed that the ointment containing the $A$. baccifera and $B$. maderaspatensis leaf extracts had a positive effect toward cellular proliferation, granulation 
tissue formation, and epithelialization. The treated rats showed marked epithelialization, a moderate amount of extracellular matrix synthesis, and new blood vessel formation.

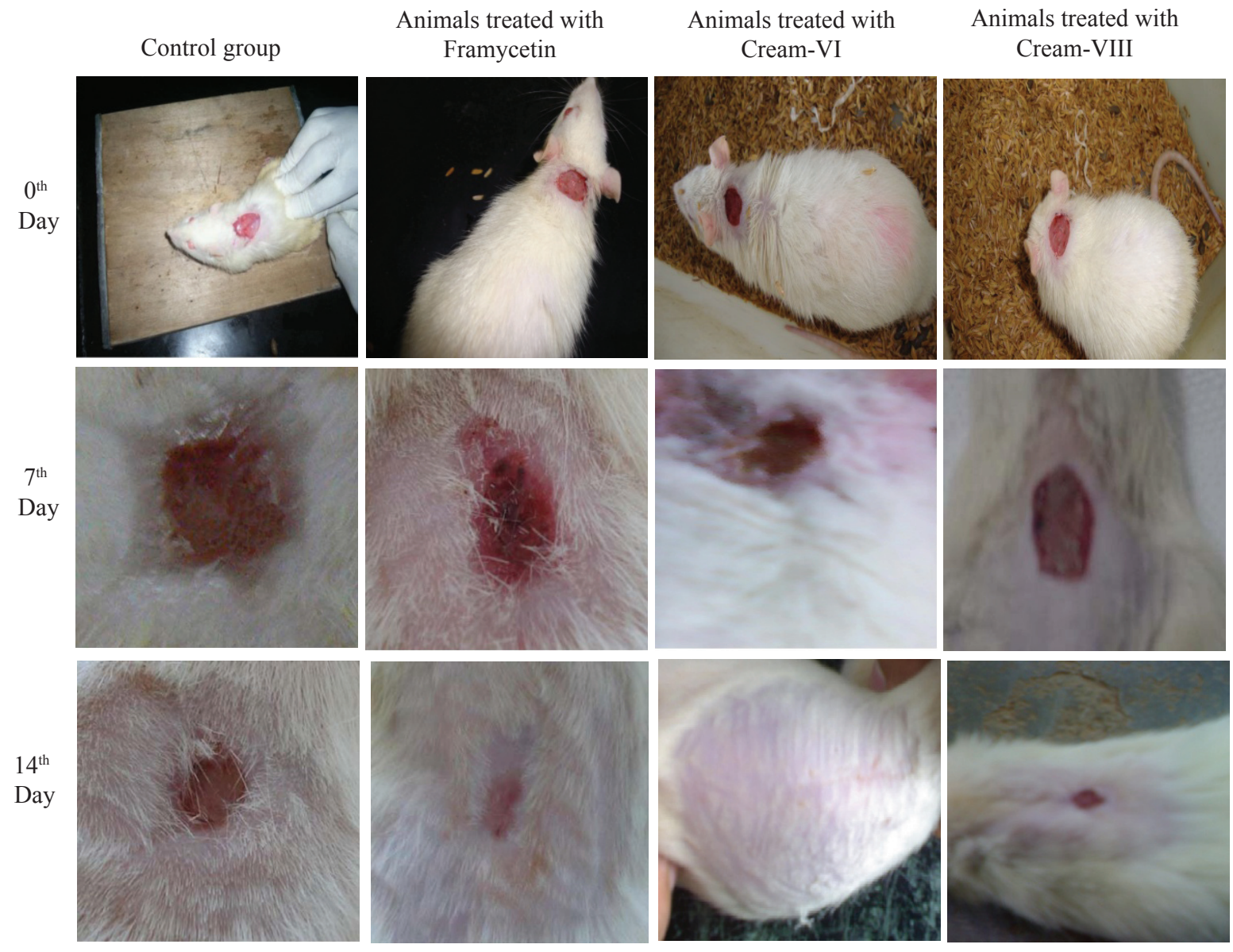

Figure 3. Photographical representation of contraction rate on different days in control and treated groups.
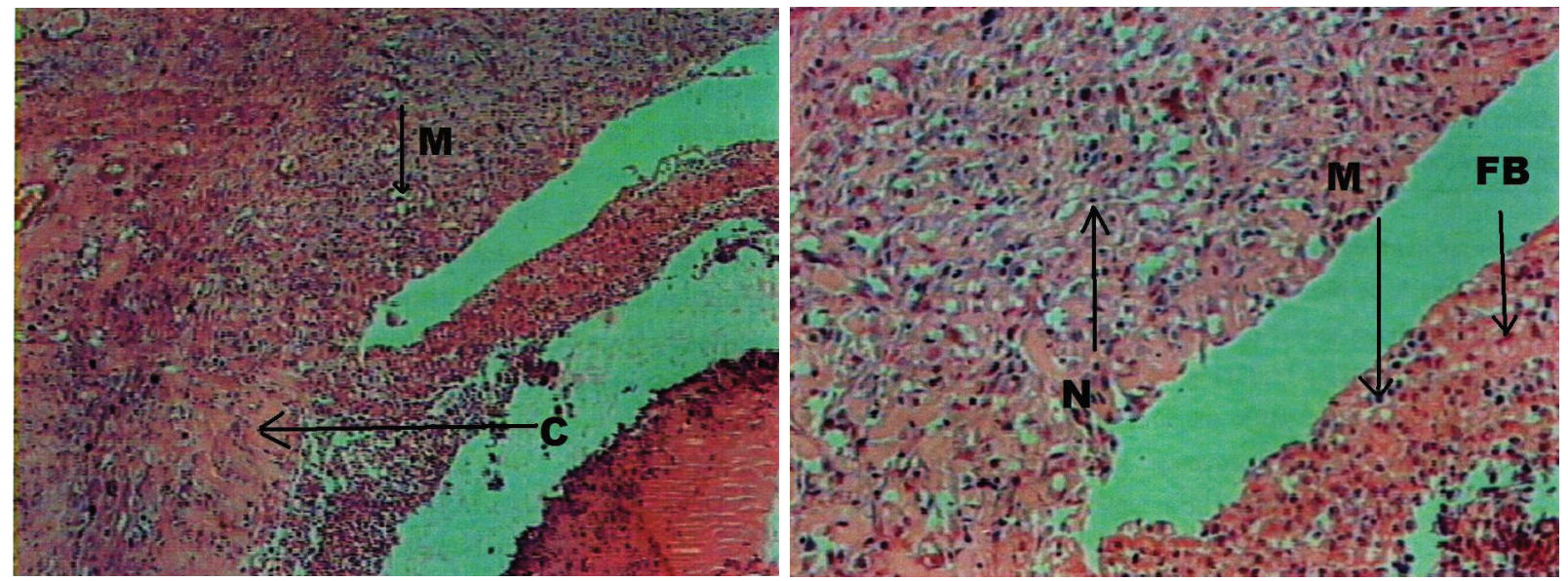

Figure 4. Histology of the skin of group 1 animals by H and E Stain in 40x and 100x respectively.M-Macrophage, C-Collagen, N-Neutrophil, FB-Fibroblast. 

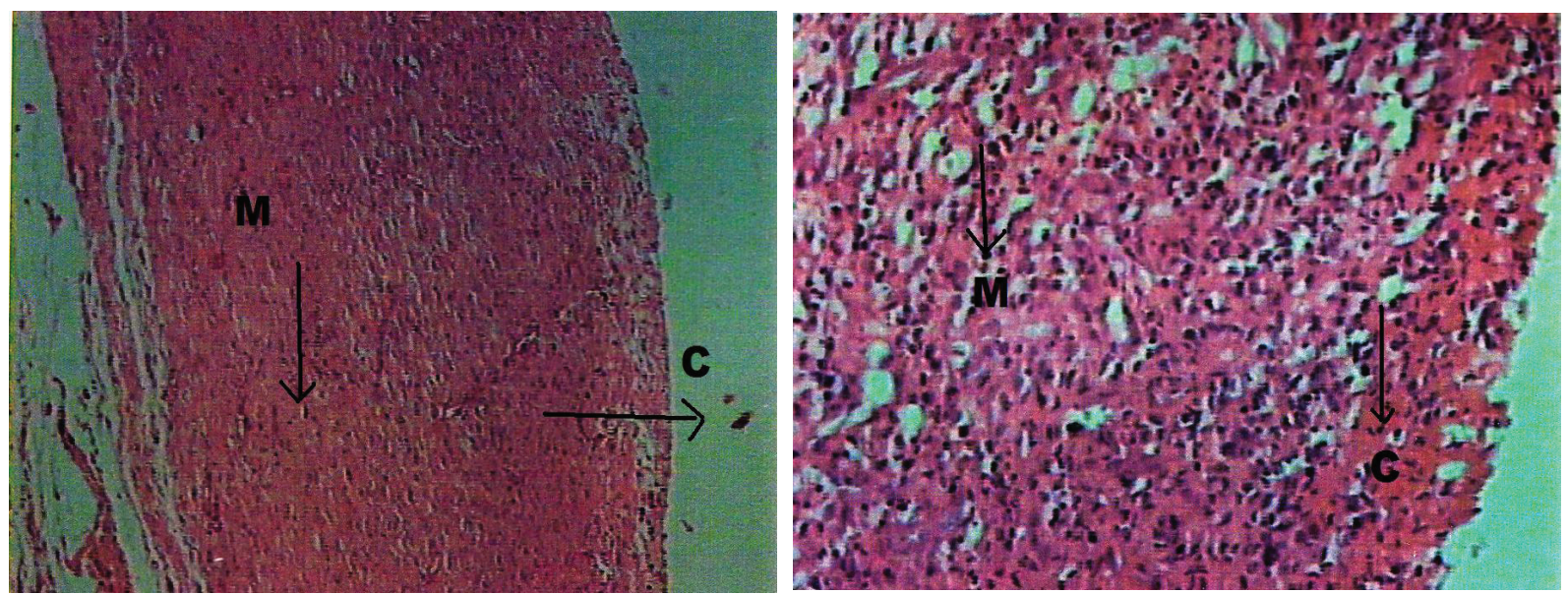

Figure 5. Histology of the skin of group 2 animals by H\&E Stain in 40x and 100x respectively. M-Macrophage, C-Collagen, N-Neutrophil, FB-Fibroblast.
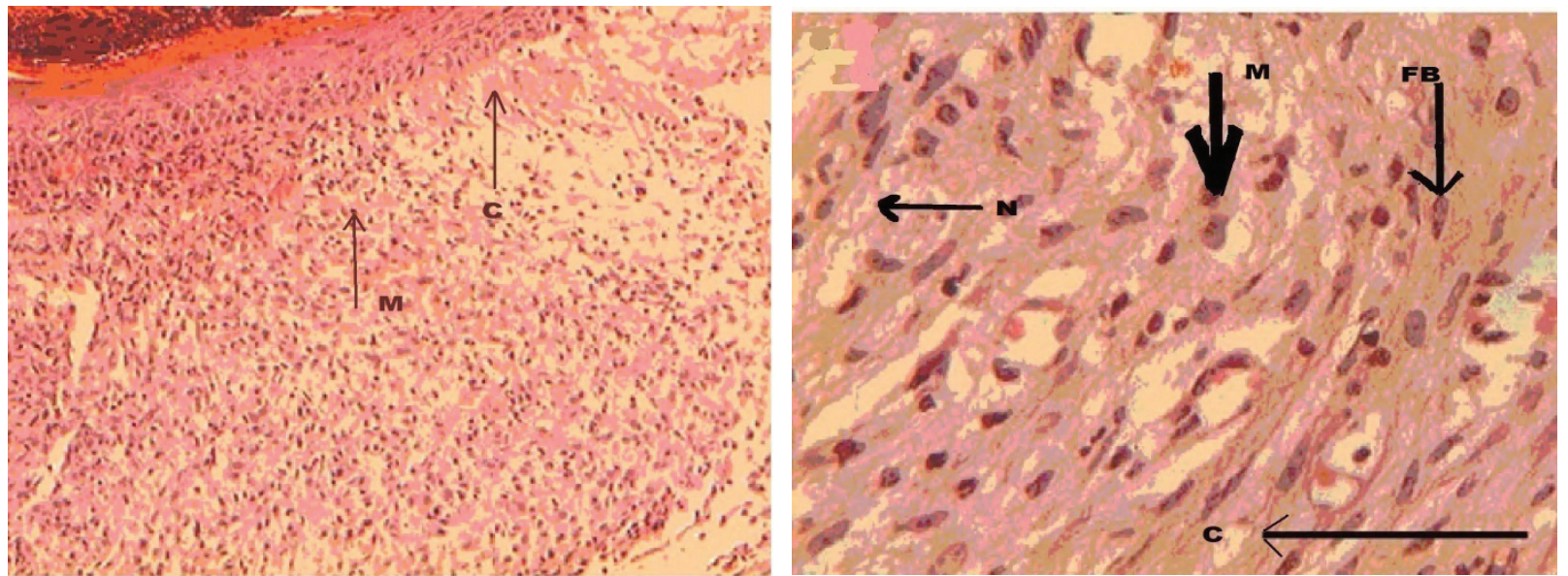

Figure 6. Histology of the skin of group 8 animals by H\&E Stain in 40x and 100x respectively. M-Macrophage, C-Collagen, N-Neutrophil, FB-Fibroblast.
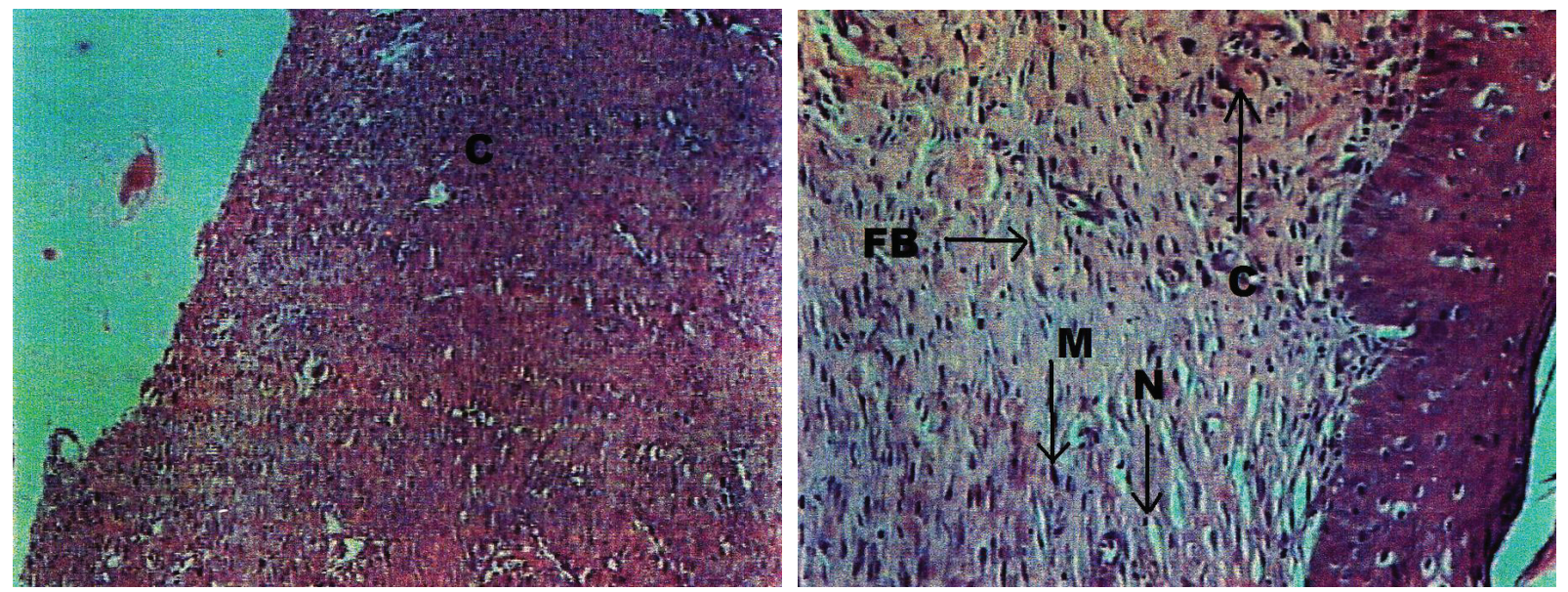

Figure 7. Histology of the skin of group 10 animals by H\&E Stain in 40x and 100x respectively. M-Macrophage, C-Collagen, N-Neutrophil, FB-Fibroblast. 


\section{Conclusions}

The application of leaf extracts of Ammannia baccifera L., Lythraceae, and a Blepharis maderaspatensis (L.) B.Heyne ex Roth., Acanthaceae, cream to an infected wound not only reduces the risk of further infection, but also improves the healing activity. The application of ethanolic leaf extracts of $A$. baccifera and $B$. maderaspatensis was found to improve the different phases of wound repair, including collagen synthesis and maturation, wound contraction and epithelialization. The leaf extracts/fractions of the two plants which are extensively used in both traditional and folk systems of medicine of India reported in ethno botanical literature for use in the healing of wounds are found to be true and can be effectively used in the modern system of medicine after isolating and purifying the phytoconstituents responsible for the activity.

\section{References}

Adam JS, Richarada FC 1999. Cutaneous wound healing. New Engl J Med 341: 738-746.

Ayyanar M, Sankarasivaraman K, Ignacimuthu S 2008. Traditional Healing Potential of Paliyars in Southern India. Ethno Leaflets 12: 311-317.

Bhuvaneshwar U, Dhaker AK, Ashwani K 2010. Ethnomedicinal and ethnopharmaco-statistical studies of Eastern Rajasthan, India. J Ethnopharmacol. 129: 64-86.

Ehrlich HP, Hunt TK 1968. The effect of cortisone and anabolic steroids on the tensile strength of healing wounds. Ann Surg 57: 117-120.

Ganesan S, Ramar Pandi N, BanumathiN 2007. Ethnomedicinal Survey of Alagarkoil Hills (Reserved Forest), Tamil Nadu, India. Ethno Leaflets 1: 1-19.

Harborne JB 1998. Methods of extraction and isolation, in: Phytochemical methods. Chapman and Hall, London.

Ignacimuthu S, Ayyanar M Sankara Sivaraman K 2006. Ethno botanical investigations among tribes in Madurai District of Tamil Nadu (India). J Ethnobiol Ethnomed 2: 25-27.

Ignacimuthu S, Ayyanar M, Sankarasivaraman K. 2008 Ethnobotanical study of medicinal plants used by Paliyar tribals in Theni district of Tamil Nadu, India. Fitoterapia 79: 562-568.

Jagtap NS, Khadabadi SS, Farooqui IA 2009. Development and evaluation of herbal wound healing formulations Int J PharmTech Res 1: 1104-1108.

Jain V, Prasad V, Pandey RS 2006. Wound healing activity of Desmodium gangeticum in different wound model. $J$ Plant Sci 3: 247-253.

Kapoor LD, Singh A, Kapoort SL 1969. Survey of Indian medicinal plants for saponins, alkaloids and flavonoids. Lloyd 32: 297-302.

Kottaimuthu R 2008. Ethnobotany of the Valaiyans of
Karandamalai, Dindigul District, Tamil Nadu. Ethno Leaflets 12: 195-203.

Kumar B, Vijayakumar M, Govindarajan R 2007. Ethnopharmacological approaches to wound healingexploring medicinal plants of India. J Ethnopharmacol 114: 103-113.

Lee KH 1968. Study on the mechanism of action of salicylates II, Retardation of wound healing by aspirin. J Pharm. Sci. 57: 1042-1043.

Madden JW, Peacock E 1968. Studies on the biology of collagen during wound healing. Rate of collagen synthesis and deposition in cutaneous wounds of the rat. Surgery. 64: 288-292.

Mcmanus JGA, Mowry RW 1984. Staining Methods: Histological and Histochemical; Harper and Row: New York, NY, USA.

Morton JJP, Malone MH 1972. Evaluation of vulnerary activity by an open procedure in rats. Arch. Int. Pharmacodyn ther 196: 117-126.

Nayak BS, 2006. Cecropia peltata L (Cecropiaceae) has woundhealing potential: a preclinical study in a Sprague Dawley rat model. Int J Low Extrem Wounds 5: 20-26.

Nayak BS, Ramdath DD, Marshall JR 2010. Wound healing activity of the skin of the common grape (Vitis vinifera) Variant, Cabernet Sauvignon. Phytother Res. 24: 11511157.

OECD (Organization for Economic Co-operation and Development) Guideline for testing of chemicals Guideline No. 402, Adopted: 24 Feb 1987, 1-7.

Okoli CO, Ezike AC, Akah PA 2009. Studies on Wound Healing and Antiulcer Activities of Extract of Aerial Parts of Phyllanthus niruri. Am J Pharmacol Toxicol 4: 118-126

Pritam SJ, Sanjay BB 2010. Evaluation of wound healing effect of petroleum ether and methanolic extract of Abelmoschus manihot 9L.) Medikik, Malvaceae, and Wrightia tinctoria R.Br., Apocyanaceae in rats. Braz J Pharmacogn 20: 756-271.

Said HM 1956. Medicinal Herbal, A Textbook for Medical Students and Doctors; Bait Al-Hikmah: Madinat AlHikmah, Karachi, Pakistan.

Scortichini M, Pia Rossi M 1991. Preliminary in vitro evaluation of the antimicrobial activity of triterpenes and terpenoids towards Erwinia amylovora (Burrill). J Bacteriol 71: 109-112.

Suresh Reddy J, Rajeswara Rao P, Reddy MS 2002. Wound healing effects of Heliotropium indicum, Plumbago zeylanicum and Acalypha indica in rats. J Ethnopharmacol 79: 249251.

Udupa AL, Kulkarni DR, Udupa SL 1995. Effect of Tridax procumbans extracts on wound healing. Int $J$ Pharmacogn 33: 37-40.

Vanila D, Ghanthikumar S, Manickam VS 2008. Ethnomedicinal Uses of Plants in the Plains area of the TirunelveliDistrict, Tamilnadu. Ethno Leaflets 12: 1198-1205 


\section{*Correspondence}

A. Rajasekaran

KMCH College of Pharmacy,

Kovai Estate, Kalapatti Road,Coimbatore -641 048,

Tamilnadu, India

Tel: +91 422291 7282; 22629007 